\title{
Quality of Soppressata salami from Pugliese Pigs as Affected by Rearing System
}

\author{
Marzia Albenzio*, Antonella Santillo, Rosaria Marino, Francesca d'Angelo, \\ Mariangela Caroprese, Agostino Sevi \\ Department of the Sciences of Agriculture, Food and Environment, University of Foggia, Foggia, Italy \\ Email: * marzia.albenzio@unifg.it
}

Received 20 December 2013; revised 20 January 2014; accepted 27 January 2014

Copyright (C) 2014 by authors and Scientific Research Publishing Inc.

This work is licensed under the Creative Commons Attribution International License (CC BY). http://creativecommons.org/licenses/by/4.0/

(c) (i) Open Access

\begin{abstract}
Twenty four male pigs were assigned to two groups of 12 each during the last fattening phase: one group was reared outdoor (OUT group) and fed on natural pasture, while the other group was reared indoor (IND group) and fed on commercial feedstuff. Meat was processed into Soppressata salami according to traditional protocol. Meat and Soppressata salami were analyzed for nutritional, textural and color parameters. Meat and Soppressata salami showed significantly higher proportion of unsaturated fatty acids in OUT than that in IND group. Ameliorated nutritional indexes in terms of n-6/n-3 ratio, and thrombogenic index were found both in meat and Soppressata salami in OUT group. Texture Profile Analysis showed lower values in the tested samples from OUT than IND group. Lightness, redness, and chroma parameters were higher both in meat and Soppressata salami in OUT group; whereas hue parameter was lower in Soppressata salami from OUT pigs. Outdoor rearing improved fatty acid profile, nutritional indexes, color and mechanical properties of pork meat thanks to natural pasture, greater space allowance and physical exercise of animal during the fattening phase. Meat features strictly affected the quality of the Soppressata salami produced by using traditional protocol.
\end{abstract}

\section{Keywords}

Pig Meat; Soppressata salami; Nutritional Properties; Textural Properties; Meat Color

\section{Introduction}

Pig meat consumed in developed countries is mainly obtained from selected pig breeds which were raised under intensive condition [1]. This system has involved an increasing public concern for animal welfare, environmen-

*Corresponding author. 
tal pollution and safety of meat products [2].

Increasing interest is paid to the production of meat and meat products from autochthonous pig breeds. From European inventories, 25 such local breeds exist in EU countries, and five in Italy [3]. These breeds produce excellent quality of meat that is mainly used for typical regional salami and cold cuts, including PDO branded products such as Salsiccia, Soppressata, Capocollo, and Pancetta [4] [5]. Pugliese pig comes from Napoletana pig breed, one of the most ancient swine breeds in Southern Italy [6]. Pugliese breed is reared in Apulia region and it is characterized by black skin with hard bristles, and sometimes there can be white spots on the face and at the ends, and most rare skin could be completely white. This is a very rustic breed well adapted to extreme climates from the sultry hot summer to the hard winter climate of Apennine; it is an excellent grazer, noticeable for its remarkable frugality and feeding versatility and it is particularly suitable for wild or semi-wild management.

One of the most appreciated products obtained from autochthonous pig meat is the Soppressata salami that represents a traditional Southern Italian dry sausage associated with the perception of typical food quality by artisanal food consumers [7] [8]. Main ingredients in traditional Soppressata salami are fat cuts (100 - $150 \mathrm{~g} / \mathrm{Kg}$ ), pork lean, pepper or chili pepper, red wine and salt. The process parameters provide for coarse cutting, filling on natural skin and ripening under controlled conditions over about 50 days [7].

The aim of the present study was to investigate nutritional, textural properties and color of Soppressata salami obtained from Pugliese pigs reared outdoor and fed on natural pasture or reared indoor and fed commercial feedstuff.

\section{Materials and Methods}

\subsection{Experimental Design}

All the procedures were conducted according to the guidelines of the Council Directive 86/609/EEC of 24 November 1986 on the protection of animals used for experimental and other scientific purposes [9].

Twenty four male Pugliese pigs were used in the experiment; after weaning pigs were randomly distributed in two groups of 12 each. One group was reared outdoor (OUT group) in woodland mainly composed of the Quercus genus (Quercus ilex and, more rarely, Q. robur), beech (Fagus saelvatica) and chestnut (Castanea sativa) trees, sub-fruiticose plants (Diplotaxis tenuifolia, Thymus striatus), annual and perennial grasses like leguminosae (Vicia, medicago sativa), and Graminaceae (Lolium, Phleum). The other group was reared indoor (IND group) and fed on commercial feedstuff, administered at $30 \mathrm{~g} / \mathrm{Kg}$ of live weight, including maize meal, wheat meal, wheat bran, soy meal, molasses, vitamin mixture and mineral, the chemical composition is shown in Table 1. Body weights at slaughter were $140 \pm 21 \mathrm{~kg}$ for indoor and $135 \pm 26 \mathrm{~kg}$ for outdoor pigs, respectively. Soppressata salami was produced using lean pork (shoulder, tenderloin, ham); prior to Soppressata production samples of raw meat for each pig were collected and analysed in duplicate for the nutritional, mechanical and color parameters.

Table 1. Chemical and fatty acid composition of the commercial feedstuff ${ }^{\mathrm{a}}$ given to indoor Pugliese pigs.

\begin{tabular}{ccc}
\hline & Chemical composition $(\mathrm{g} / \mathrm{Kg})$ & \\
\hline Crude protein & 160 \\
Total fat & 52 \\
Crude fiber & 65 \\
Ash & 65 \\
\hline & Fatty acid composition $(\mathrm{g} / \mathrm{Kg})$ & \\
\hline C14:0 & 16 \\
C16:0 & 147 \\
C18:0 & 25 \\
C18:1 & 219 \\
C18:2 n-6 & 538 \\
C18:3 n-3 & 41 \\
\hline
\end{tabular}

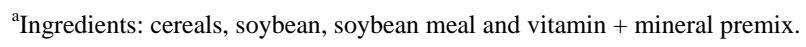


Three Soppressata salami were produced, from each animal, in an industrial plant according to the traditional protocol; briefly, defatted pork meat was hanged at $0^{\circ} \mathrm{C}-2^{\circ} \mathrm{C}$ for $2-3$ days and then minced. A mixture of pork meat, fat cuts (50 - $70 \mathrm{~g} / \mathrm{Kg}), \mathrm{NaCl}(20 \mathrm{~g} / \mathrm{Kg})$, black pepper in grains $(3 \mathrm{~g} / \mathrm{Kg})$, and white wine $(20 \mathrm{~g} / \mathrm{Kg}) \mathrm{was}$ left undisturbed for $24 \mathrm{~h}$ at about $4^{\circ} \mathrm{C}$, and then used to fill natural casings. After filling, the product was pressed for $48 \mathrm{~h}$ at room temperature; the product was dried for $3 \mathrm{~d}$ during this time relative humidity decreasing from 80 to $75 \%$ and temperature decreasing from $25^{\circ} \mathrm{C}$ to $15^{\circ} \mathrm{C}$. Subsequent ripening stage was carried out for 45 - 50 $\mathrm{d}$ in store rooms at $70 \%-75 \%$ relative humidity, and $10^{\circ} \mathrm{C}-14^{\circ} \mathrm{C}$. The product obtained was cylindrical, $15-20$ $\mathrm{cm}$ in length and $4-6 \mathrm{~cm}$ in diameter. Soppressata salami was analyzed in duplicate for nutritional, mechanical and color parameters.

\subsection{Nutritional Analysis on Meat and Soppressata salami}

Moisture, protein, and lipid contents in meat and Soppressata salami samples were determined according to AOAC methods [10]. Protein content was determined using the Kjeldahl method, briefly one gram of sample, one Kjeltec catalyst tablet and $10 \mathrm{~mL} \mathrm{H}_{2} \mathrm{SO}_{4}$ was put into Kjeldahl tube and digested for $2 \mathrm{~h}$ at $420^{\circ} \mathrm{C}$. The product was then made basic with $30 \%(\mathrm{w} / \mathrm{v}) \mathrm{NaOH}$ before distillation into $0.1 \mathrm{M} \mathrm{HCl}$ and titration against 0.25 $\mathrm{M} \mathrm{NaOH}$. The factor used to convert nitrogen into crude protein was 6.25. Moisture content was determined after drying ten grams of sample at $105^{\circ} \mathrm{C}$ for $24 \mathrm{~h}$; the water content of the samples was gravimetrically determined. Lipids for fatty acid composition were extracted according to previous studies [11]. Duplicate samples of chloroform extract, corresponding to $100 \mathrm{mg}$ of lipid, were methylated according to IUPAC [12]. Gas-chromatography analysis was performed using a gas chromatograph 6890N (Agilent Technologies, Santa Clara, CA., USA) equipped with a HP-88 capillary column (length $100 \mathrm{~m}$, internal diameter $0.25 \mathrm{~mm}$, film thickness 0.25 $\mu \mathrm{m}$, Agilent Technologies). The operating conditions were: a FID detector at $260^{\circ} \mathrm{C}$; a split-splitless injector at $260^{\circ} \mathrm{C}$ with an injection volume of $1 \mu \mathrm{l}$. The split ratio was 1:50 and helium was gas carrier with a pressure of $33 \mathrm{psi}$. The programmed temperature was $100^{\circ} \mathrm{C}$ for $1 \mathrm{~min}$, increased to $240^{\circ} \mathrm{C}$ at a rate of $3.5^{\circ} \mathrm{C} / \mathrm{min}$, maintained at $240^{\circ} \mathrm{C}$ for $15 \mathrm{~min}$. Retention time and area of each peak were computed using the 6890N NETWORK GC system software. Individual fatty acids methyl esters (FAME) peaks were identified by comparing their retention times with those of standards (Supelco ${ }^{\circledR} 37$ Component FAME Mix, 47885U-Supelco, Sigma-Aldrich, St. Louis, MO., USA). Results are expressed as percentage of the total fatty acids analysed and saturated (SFA), monounsaturated (MUFA) and polyunsaturated (PUFA) fatty acids were determined. Atherogenic and thrombogenic indexes were calculated according to Ulbricht and Southgate [13] as follows:

Atherogenic Index $(\mathrm{AI})=(\mathrm{C} 12: 0+4 \times \mathrm{C} 14: 0+\mathrm{C} 16: 0) /\left(\sum \operatorname{MUFA}+\sum \operatorname{PUFA}(\omega-6)\right.$ and $\left.(\omega-3)\right)$

Thrombogenic Index (TI)

$=(\mathrm{C} 14: 0+\mathrm{C} 16: 0+\mathrm{C} 18: 0) /\left[\left(0.5 \times \sum \operatorname{MUFA}+0.5 \times \sum \operatorname{PUFA}(\mathrm{n}-6)+3 \times \sum \operatorname{PUFA}(\mathrm{n}-3)+(\mathrm{n}-3) /(\mathrm{n}-6)\right)\right]$.

\subsection{Instrumental Texture}

Warner-Bratzler Shear Force (WBSF) and Texture Profile Analysis (TPA) were tested on meat and Soppressata salami using two different instrumental measurements. Ten parallelepiped for each samples $\left(1 \mathrm{~cm}^{2}\right.$ in cross-section) were cut with muscle fibres parallel to the longitudinal axis of the sample. A 3343 universal testing machine (Instron Ltd., High Wycombe, United Kingdom) was used in both instrumental tests. The shear force evaluation was assessed using a Warner-Bratzler (WB) device, which measures the peak force (kg) required to cut the parallelepiped in half perpendicular to its length. Samples were sheared perpendicular to the fibre at 100 $\mathrm{mm} / \mathrm{min}$ crosshead speed using a $100 \mathrm{~kg}$ load cell.

Texture profile was analysed using a modified compression device that avoids transversal elongation of the samples. Each sample underwent two cycles of $80 \%$ compression. Force by time data was used to calculate the following parameters: hardness, cohesiveness, springiness, gumminess, chewiness. In each instrumental test five replicates were performed for each sample.

\subsection{Meat Color}

Color was measured using a color meter CR 200 ( $\mathrm{D}_{65}$ : illuminant; Konica Minolta Sensing Inc., Sakai-ku, Sakai, Osaka, Japan) on $1 \mathrm{~cm}$ thick steaks thawed for $12 \mathrm{~h}$ at $2^{\circ} \mathrm{C}$. Before measurement, meat samples were allowed to 
bloom for $1 \mathrm{~h}$ at $3^{\circ} \mathrm{C} \pm 1^{\circ} \mathrm{C}$, stored in a plastic tray and over wrapped with a polyethylene film. Commission International de l'Eclairage color coordinates [14] were measured: lightness $\left(\mathrm{L}^{*}\right)$, redness $\left(\mathrm{a}^{*}\right)$ and yellowness

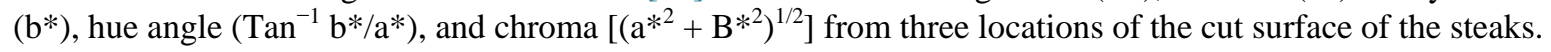

\subsection{Statistical Analyses}

Data were subjected to an analysis of variance (ANOVA), using the GLM procedure of the SAS statistical software [15].

The model utilized was:

$$
\mathrm{y}_{\mathrm{ijk}}=\mu+\alpha_{\mathrm{i}}+\beta_{\mathrm{ij}}+\varepsilon_{\mathrm{ijk}}
$$

where: $\mu$ is the overall mean; $\alpha$ is the effect of rearing system (i=1-2); $\beta$ is individual animal variation within rearing system, and $\varepsilon$ is the error. All effects were tested for statistical significance (at $\mathrm{P}<0.05$ ) and significant effects were reported in tables. When significant effects were found (at $\mathrm{P}<0.05$, unless otherwise noted), the Student $t$-test was used to locate significant differences between means.

\section{Results and Discussion}

\subsection{Nutritional Analysis on Meat and Soppressata salami}

Chemical composition of both Pugliese pig meat and Soppressata salami were not affected by rearing system. Mean values were $709.00 \pm 13.30 \mathrm{~g} / \mathrm{Kg}$ for moisture; $238.00 \pm 5.90 \mathrm{~g} / \mathrm{Kg}$ for protein content and $39.00 \pm 9.60$ $\mathrm{g} / \mathrm{Kg}$ for intramuscular fat content in meat. Mean values were $402.00 \pm 6.50 \mathrm{~g} / \mathrm{Kg}$ for moisture, $293.00 \pm 5.20$ $\mathrm{g} / \mathrm{Kg}$ for protein content and $221.80 \pm 4.50 \mathrm{~g} / \mathrm{Kg}$ for fat content in Soppressata salami.

Literature data on gross composition of Italian pigs meat refer to animals of different age/weight at slaughter, diet, and rearing systems. In the present study pork lean meat was representative of a pool of different muscles so that results from meat chemical composition are not easily to compare with data reported in literature. However, several authors report that rearing system affects a number of chemical and physical traits of pig meat but the highest characterization occurs on the adipose tissue [16]. Although no differences emerged in the fat content, meat fatty acid profile was influenced by the rearing system. Fatty acid composition of meat from Pugliese pig breed subjected to different rearing system is reported in Table 2. Lower levels of 14:0, 16:0, and c9, c1218:2 and higher levels of c9-18:1, 18:3 n-6, 18:3 n-3 and 22:6 n-3 were found in meat from OUT than IND group.

Fatty acid composition of Soppressata salami produced using meat obtained from Pugliese pig reared outdoor and indoor is reported in Table 3. Lower content of 16:0 and higher content of c9-18:1, 18:3 n-3, and 18:3 n-6 were observed in Soppressata salami from OUT than IND group. Lower values were reported for SFA, n-6, $\mathrm{n}-6 / \mathrm{n}-3$ ratio, and TI in OUT than IND group.

Meat from OUT group evidenced higher levels of oleic acid, which represents the most abundant fatty acid in pork meat [17]-[19]; in particular, late-maturing local pig breeds show greater predisposition to deposit this fatty acid [20] [21]. Outdoor rearing system influenced MUFA content, primarily oleic acid content in meat according to Pugliese et al. [16] and Ruiz-Carrascal et al. [22]. In this study the higher level of oleic acid in meat from OUT group was ascribed to the diet consisting on woodland products, mainly chestnut and acorn, during the fattening phase. Apart from rearing system, meat from the Pugliese pig evidenced higher proportion of n-3 and lower proportion of $n-6$ as well as lower $n-6 / n-3$ ratio than levels reported both for commercial breeds as Landrace $\times$ Large White pigs [23] [24], and for autochthonous breeds, such as Cinta Senese pigs [25], Nero Siciliano pigs [16], Casertana and Mora Romagnola pigs [26].

General chemical parameters of Soppressata salami were comparable with meat products of such a type as Coppa and Salame Milano [27]. Soppressata salami from Pugliese pig presented higher levels of linoleic acid, $\mathrm{n}-3$, and PUFA than those observed in typical Italian salami [27]-[29]. Fatty acids profile of Soppressata salami matched data found in the corresponding meat confirming that rearing system, and in particular feeding regimen, was able to influence nutritional value of meat and meat products. Oleic acid is of particular interest from a nutritional point of view for its hypolipidemic properties and for its involvement in reducing both plasma cholesterol and triglycerides [30]. Gamma-linolenic acid (GLA) is also responsible for human health benefit; indeed, GLA, via conversion to prostaglandin E1, exhibits anti-inflammatory, anti-thrombotic, and lipid-lowering 
Table 2. Fatty acids composition (g/Kg) of meat from Pugliese pigs when reared outdoor and fed on natural pasture or reared indoor and fed commercial feedstuff. Means \pm Standard Deviation.

\begin{tabular}{|c|c|c|c|}
\hline \multicolumn{4}{|c|}{ Rearing system } \\
\hline Parameter & Outdoor & Indoor & Effect, $P$ \\
\hline $14: 0$ & $15.10 \pm 3.43$ & $23.00 \pm 3.45$ & $<0.01$ \\
\hline $16: 0$ & $256.30 \pm 11.27$ & $275.10 \pm 11.29$ & $<0.05$ \\
\hline $16: 1$ & $39.20 \pm 8.82$ & $38.30 \pm 8.83$ & 0.29 \\
\hline 18:0 & $118.10 \pm 9.56$ & $122.80 \pm 9.55$ & 0.32 \\
\hline c9-18:1 & $443.20 \pm 10.29$ & $411.50 \pm 10.27$ & $<0.01$ \\
\hline c9,c12-18:2 & $91.90 \pm 9.31$ & $112.20 \pm 9.33$ & $<0.01$ \\
\hline $18: 3 n-6$ & $11.70 \pm 5.64$ & ND & $<0.001$ \\
\hline $18: 3 n-3$ & $13.20 \pm 3.68$ & $8.00 \pm 3.67$ & $<0.05$ \\
\hline $20: 3 n-6$ & $4.70 \pm 4.41$ & $6.00 \pm 4.39$ & 0.25 \\
\hline $20: 3 n-3$ & $5.30 \pm 3.18$ & $6.10 \pm 3.20$ & 0.36 \\
\hline $22: 6$ n3 & $1.40 \pm 0.43$ & $0.10 \pm 0.18$ & $<0.01$ \\
\hline n3 & $19.80 \pm 3.92$ & $14.20 \pm 3.90$ & $<0.05$ \\
\hline n6 & $108.30 \pm 4.41$ & $115.20 \pm 4.39$ & $<0.05$ \\
\hline SFA & $389.50 \pm 14.45$ & $420.90 \pm 14.46$ & $<0.001$ \\
\hline MUFA & $482.40 \pm 11.02$ & $449.80 \pm 11.03$ & $<0.05$ \\
\hline PUFA & $128.10 \pm 10.04$ & $129.40 \pm 10.05$ & 0.24 \\
\hline $\mathrm{P} / \mathrm{S}$ & $0.33 \pm 0.12$ & $0.31 \pm 0.13$ & 0.32 \\
\hline n6/n3 & $5.48 \pm 0.36$ & $8.20 \pm 0.37$ & $<0.01$ \\
\hline $\mathrm{AI}^{1}$ & $0.53 \pm 0.05$ & $0.59 \pm 0.04$ & 0.65 \\
\hline $\mathrm{TI}^{2}$ & $1.14 \pm 0.07$ & $1.25 \pm 0.07$ & $<0.05$ \\
\hline
\end{tabular}

${ }^{1} \mathrm{AI}=$ Atherogenic Index; ${ }^{2} \mathrm{TI}=$ Thromobogenic Index.

Table 3. Fatty acids composition (g/Kg) of Soppressata salami obtained from Pugliese pigs when reared outdoor and fed on natural pasture or reared indoor and fed commercial feedstuff. Means \pm Standard Deviation.

\begin{tabular}{|c|c|c|c|}
\hline \multicolumn{4}{|c|}{ Rearing system } \\
\hline Parameter & Outdoor & Indoor & Effect, $P$ \\
\hline $14: 0$ & $14.40 \pm 0.14$ & $15.50 \pm 0.15$ & 0.55 \\
\hline $16: 0$ & $253.20 \pm 0.41$ & $273.10 \pm 0.35$ & $<0.001$ \\
\hline $16: 1$ & $28.50 \pm 0.03$ & $25.60 \pm 0.20$ & 0.45 \\
\hline $18: 0$ & $131.90 \pm 0.41$ & $129.20 \pm 0.09$ & 0.48 \\
\hline с9-18:1 & $428.60 \pm 2.76$ & $406.70 \pm 1.19$ & $<0.01$ \\
\hline c9,c12-18:2 & $122.50 \pm 3.43$ & $135.60 \pm 1.75$ & 0.36 \\
\hline $18: 3 n-6$ & $6.50 \pm 0.30$ & $1.50 \pm 0.32$ & $<0.01$ \\
\hline $18: 3 n-3$ & $9.80 \pm 0.10$ & $7.00 \pm 0.10$ & $<0.05$ \\
\hline $20: 3 n-6$ & $1.10 \pm 0.12$ & $1.70 \pm 0.03$ & 0.45 \\
\hline $20: 3 n-3$ & $3.50 \pm 0.23$ & $4.10 \pm 0.13$ & 0.38 \\
\hline n3 & $13.30 \pm 0.32$ & $11.10 \pm 0.21$ & 0.42 \\
\hline $\mathrm{n} 6$ & $130.10 \pm 3.76$ & $138.80 \pm 1.83$ & $<0.05$ \\
\hline SFA & $399.50 \pm 0.96$ & $417.80 \pm 0.44$ & $<0.05$ \\
\hline MUFA & $457.10 \pm 2.80$ & $432.30 \pm 1.44$ & $<0.001$ \\
\hline PUFA & $143.40 \pm 4.27$ & $149.90 \pm 2.25$ & 0.43 \\
\hline $\mathrm{P} / \mathrm{S}$ & $0.36 \pm 0.11$ & $0.36 \pm 0.06$ & 0.38 \\
\hline n6/n3 & $9.78 \pm 0.31$ & $12.50 \pm 0.20$ & $<0.05$ \\
\hline $\mathrm{AI}^{1}$ & $0.51 \pm 0.03$ & $0.55 \pm 0.02$ & 0.82 \\
\hline $\mathrm{TI}^{2}$ & $1.12 \pm 0.08$ & $1.34 \pm 0.04$ & $<0.01$ \\
\hline
\end{tabular}

\footnotetext{
${ }^{1} \mathrm{AI}=$ Atherogenic Index; ${ }^{2} \mathrm{TI}=$ Thromobogenic Index
} 
potential. Moreover essential fatty acids, including GLA, are constituents of membrane phospholipids enhancing integrity and fluidity of the membrane [31]. Thrombogenic index, calculated on the basis of acidic composition, takes into account the different effect that single fatty acid can have on human health and in particular indicates the risk associated to develop thrombosis upon food consumption. In this study, fatty acid profile led to a lower TI index in outdoor than indoor group confirming the role of rearing system in producing healthier meat and meat products.

\subsection{Instrumental Texture}

WBS and TPA parameters of meat and Soppressata salami obtained from Pugliese pigs reared outdoor and indoor is shown in Table 4. WBS was not influenced by rearing system both in meat and Soppressata salami, whereas TPA parameters showed lower values in samples from OUT pigs. Lower hardness, cohesiveness, springiness, gumminess, and chewiness were observed in Soppressata salami obtained from OUT group. TPA parameters evidenced that the characteristics of Soppressata salami followed closely features of the corresponding meat. Lower hardness, cohesiveness, springiness, gumminess, and chewiness in OUT products were ascribed to the fatty acid composition characterized by high proportion of unsaturation of the carbon chain. Wood et al. [32] reported that the effect of fatty acids on firmness is due to different melting points of the fatty acids as when saturation increases melting point declines. Furthermore, Maw et al. [33] reported that hardness of the fat samples was related to fatty acid composition showing that increased softness was associated with increased linoleic and $\alpha$-linolenic acids and decreased stearic and palmitic acid percentages. Soto et al. [34] found that raising Iberian pigs indoor leads to harder dry cured loin probably due to low fat content, high SFA, low unsaturated fatty acids content and to a lower proteolysis degree.

In this study WBS and hardness in meat and Soppressata salami were lower than those reported for meat from Cinta Senese and Iberian breed [16] [34] and for Italian salami [28] [29].

\subsection{Meat Color}

Color parameters for meat and Soppressata salami from Pugliese pig reared outdoor and indoor are reported in Table 5. The effect of rearing system was significant for lightness, redness, and chroma parameters both in meat and Soppressata salami being higher in OUT than in IND group whereas hue parameter was lower in Soppressata salami made from the meat of OUT pigs. Mancini and Hunt [35] attributed color and pigmentation differences in meat to physical activity rather than feeding level and diet composition. The major space availability of OUT group and the greater possibility of exercise during the fattening phase may account for the differences in color parameters. Indeed, exercise training increased significantly the content of haem pigments and as a consequence the myoglobin concentration in the muscle [36].

Table 4. Warner-Bratzler Shear Force (WBSF) and Texture Profile Analysis (TPA) of Meat and Soppressata salami from Pugliese pigs when reared outdoor and fed on natural pasture or reared indoor and fed commercial feedstuff. Means \pm Standard Deviation.

\begin{tabular}{|c|c|c|c|c|}
\hline \multirow[b]{2}{*}{ Parameter } & \multicolumn{4}{|c|}{ Rearing system } \\
\hline & & Outdoor & Indoor & Effect, $\mathrm{P}$ \\
\hline \multirow[t]{2}{*}{ WBSF, N } & Meat & $40.80 \pm 1.13$ & $47.97 \pm 1.10$ & 0.57 \\
\hline & Soppressata & $28.15 \pm 0.77$ & $24.43 \pm 0.57$ & 0.38 \\
\hline \multirow[t]{2}{*}{ Hardness, N } & Meat & $31.20 \pm 1.35$ & $45.28 \pm 1.30$ & $<0.01$ \\
\hline & Soppressata & $37.19 \pm 9.79$ & $49.50 \pm 10.66$ & $<0.01$ \\
\hline \multirow[t]{2}{*}{ Cohesiveness } & Meat & $0.10 \pm 0.12$ & $0.22 \pm 0.15$ & $<0.01$ \\
\hline & Soppressata & $0.12 \pm 0.03$ & $0.16 \pm 0.04$ & $<0.05$ \\
\hline \multirow[t]{2}{*}{ Springiness, mm } & Meat & $7.07 \pm 0.76$ & $7.94 \pm 0.80$ & $<0.01$ \\
\hline & Soppressata & $7.57 \pm 0.37$ & $7.82 \pm 0.19$ & $<0.05$ \\
\hline \multirow[t]{2}{*}{ Gumminess, $\mathrm{N}$} & Meat & $3.12 \pm 0.34$ & $9.96 \pm 0.36$ & $<0.05$ \\
\hline & Soppressata & $4.41 \pm 1.24$ & $7.92 \pm 1.68$ & $<0.05$ \\
\hline \multirow[t]{2}{*}{ Chewiness, N/mm } & Meat & $22.06 \pm 2.75$ & $79.08 \pm 2.78$ & $<0.05$ \\
\hline & Soppressata & $33.75 \pm 1.33$ & $61.93 \pm 1.32$ & $<0.05$ \\
\hline
\end{tabular}


Table 5. Color parameters of meat and Soppressata salami from Pugliese pigs when reared outdoor and fed on natural pasture or reared indoor and fed commercial feedstuff. Means \pm Standard Deviation.

\begin{tabular}{ccccc}
\hline & & \multicolumn{2}{c}{ Rearing system } \\
\hline Parameter & & Outdoor & Indoor & Effect, P \\
\hline Lightness, L & Meat & $46.26 \pm 4.95$ & $41.70 \pm 4.90$ & $<0.05$ \\
& Soppressata & $39.59 \pm 2.92$ & $34.59 \pm 4.37$ & $<0.05$ \\
Redness, a & Meat & $10.47 \pm 2.18$ & $8.82 \pm 2.15$ & 0.05 \\
& Soppressata & $12.79 \pm 1.76$ & $9.86 \pm 1.00$ & 0.001 \\
Yellowness, b & Meat & $10.46 \pm 3.53$ & $11.2 \pm 3.50$ & 0.85 \\
& Soppressata & $5.37 \pm 1.64$ & $5.04 \pm 0.75$ & 0.96 \\
Hue, H & Meat & $48.47 \pm 9.68$ & $53.95 \pm 9.70$ & $<0.05$ \\
& Soppressata & $22.81 \pm 6.48$ & $27.01 \pm 2.28$ & $<0.05$ \\
& Meat & $15.01 \pm 6.15$ & $14.42 \pm 6.12$ & 0.88 \\
\end{tabular}

\section{Conclusion}

Outdoor rearing improved fatty acid profile, nutritional indexes, color and mechanical properties of pork meat thanks to natural pasture, greater space allowance and physical exercise of animal during the fattening phase. Meat features strictly affected the quality of the Soppressata salami produced by using traditional protocol.

\section{References}

[1] Mayoral, A.I., Dorado, M., Guillén, M.T., Robina, A., Vivo, J.M., Vázquez, C. and Ruiz, J. (1999) Development of Meat and Carcass Quality Characteristics in Iberian Pigs Reared Outdoors. Meat Science, 52, 315-324. http://dx.doi.org/10.1016/S0309-1740(99)00008-X

[2] Dransfield, E., Ngapo, T.M., Nielsen, N.A., Bredahl, L., Sjöden, P.O., Magnusson, M., Campo, M.M. and Nute, G.R. (2005) Consumer Choice and Suggested Price for Pork as Influenced by Its Appearance, Taste and Information Concerning Country of Origin and Organic Pig Production. Meat Science, 69, 61-70. http://dx.doi.org/10.1016/j.meatsci.2004.06.006

[3] FAO (2000) World Watch List for Domestic Animal Diversity. 3rd Edition, Food and Agriculture Organization, Rome.

[4] Secchiari, P.L. (2008) Nutritional and Nutraceutical Value of Foods of Animal Origin. Italian Journal of Agronomy, 3 , 73-102. http://dx.doi.org/10.4081/ija.2008.1s.73

[5] Micari, P., Racinaro, L., Sarullo, V., Carpino, S. and Marzullo, A. (2009) Zoometric Rates, Reproductive and Productive Parameters of the Apulo-Calabria Swine, Obtained in Breeding Certified by ANAS Calabria. Italian Journal of Animal Science, 8, 519-521.

[6] Bettini, F. and Pelosi, S. (2004) Local Black Pigs Performances and Diffusion in Gargano's National Park. 39th International Symposium Meat Science and Research, Rome, 10 June 2004, 265-272.

[7] Iaccarino, T., Di Monaco, R., Mincione, A., Cavella, S. and Masi, P. (2006) Influence of Information on Origin and Technology on the Consumer Response: The Case of Soppressata Salami. Food Quality and Preference, 17, 76-84. http://dx.doi.org/10.1016/j.foodqual.2005.08.005

[8] Salvatori, G., Filetti, F., Di Cesare, C., Maiorano, G., Pilla, F. and Oriani, G. (2008) Lipid Composition of Meat and Backfat from Casertana Purebreed and Crossbreed Pigs Reared Outdoors. Meat Science, 80, 623-631. http://dx.doi.org/10.1016/j.meatsci.2008.02.013

[9] Official Journal of the European Communities (1986) Approximation of Laws, Regulations and Administrative Provisions of the Member States Regarding the Protection of Animals Used for Experimental and Other Scientific Purposes. Vol. 358, Commission Regulation (EC) No 609/86.

[10] AOAC (1995) Official Methods of Analysis. 16th Edition, Association of Official Analytical Chemists, Arlington.

[11] Bligh, E.G. and Dyer, W.J. (1959) A Rapid Method of Total Lipid Extraction and Purification. Canadian Journal of Biochemistry and Physiology, 37, 911-917. http://dx.doi.org/10.1139/059-099

[12] International Union of Pure and Applied Chemistry (1987) Standard Methods for Analyses of Oils, Fats and Derivates. 7th Edition, Blackwell Scientific Publications, Oxford.

[13] Ulbricht, T.L. and Southgate, DA.T. (1991) Coronary Heart Disease: Seven Dietary Factors. Lancet, 338, 985-992. 
http://dx.doi.org/10.1016/S0963-9969(99)00153-2

[14] Commission International de l'Eclairage (1986) Colorimetry. 2nd Edition. Commission International de l'Eclairage (CIE), Publication CIE 15.2, Wien.

[15] Statistical Analysis System (1999) SAS/STAT User’s Guide (Version 8.1). Statistical Analysis System Inst, Cary.

[16] Pugliese, C., Calcagna, G., Chiofalo, V., Moretti, V.M., Margotta, S., Franci, O. and Gandini, G. (2004) Comparison of the Performances of Nero Siciliano Pigs Reared Indoors and Outdoors: 2. Joints Composition, Meat and Fat Traits. Meat Science, 68, 523-528. http://dx.doi.org/10.1016/j.meatsci.2004.02.020

[17] Enser, M., Hallett, K.G., Hewett, B., Fursey, G.A.J. and Wood, J.D. (1996) Fatty Acid Content and Composition of English Beef, Lamb and Pork at Retail. Meat Science, 42, 443-456. http://dx.doi.org/10.1016/S0309-1740(97)00144-7

[18] Nilzèn, V., Babol, J., Dutta, P.C., Lundeheim, N., Enfalt, A.C. and Lunstrom, K. (2001) Free Range Rearing of Pigs with Access to Pasture Grazing-Effect on Fatty Acid Composition and Lipid Oxidation Products. Meat Science, 58, 267-275. http://dx.doi.org/10.1016/S0309-1740(00)00164-9

[19] Wood, J.D., Enser, M., Fisher, A.V., Nute, G.R., Sheard, S.R., Richardson, R.I., Hughes, S.I. and Whittington, F.M. (2008) Fat Deposition, Fatty Acid Composition and Meat Quality: A Review. Meat Science, 78, 343-358. http://dx.doi.org/10.1016/j.meatsci.2007.07.019

[20] Gandemer, G., Pichou, D., Bouguennec, B., Caritz, J.C., Berge, P., Briant, E. and Legault, C. (1990) Influence du Système d’Élevage et du Gènotype sur la Composition Chimique et les Qualités Organoleptiques du Muscle Long Dorsal Chez le Porc. Journées de la Recherche Porcine en France, 22, 101-110.

http://www.journees-recherche-porcine.com/texte/1990/90txtQualite/Q9008.pd

[21] Lopez-Bote, C.J. (1998) Sustained Utilization of the Iberian Pig Breed. Meat Science, 49, S17-S27. http://dx.doi.org/10.1016/S0309-1740(98)90036-5

[22] Ruiz-Carrascal, J., Ventanas, J., Cava, R., Andrés, A.I. and García, C. (2000) Texture and Appearance of Dry Cured Ham as Affected by Fat Content and Fatty Acid Composition. Food Research International, 33, 91-95. http://dx.doi.org/10.1016/S0963-9969(99)00153-2

[23] Lo Fiego, D.P., Santoro, P., Macchioni, P.D. and Leonibus, E. (2005) Influence of Genetic Type, Live Weight at Slaughter and Carcass Fatness on Fatty Acid Composition of Subcutaneous Adipose Tissue of Raw Ham in the Heavy Pig. Meat Science, 69, 107-114. http://dx.doi.org/10.1016/j.meatsci.2004.06.010

[24] Martelli, G., Sardi, L., Parigini, P., Badiani, A., Parazza, P. and Mordenti, A. (2005) The Effect of a Dietary Supplement of Biotin on Italian Heavy Pigs' (160 Kg) Growth, Slaughtering Parameters, Meat Quality and the Sensory Properties of Cured Hams. Livestock Production Science, 93, 117-124. http://dx.doi.org/10.1016/j.livprodsci.2004.09.006

[25] Pugliese, C., Bozzi, R., Campodoni, G., Acciaioli, A., Franci, O. and Gandini, G. (2005) Performance of Cinta Senese Pigs Reared Outdoors and Indoors. 1. Meat and Subcutaneous Fat Characteristics. Meat Science, 69, 459-464. http://dx.doi.org/10.1016/j.meatsci.2007.01.020

[26] Fortina, R., Barbera, S., Lussiana, C., Mimosi, A., Tassone, S., Rossi, A. and Zanardi, E. (2005) Performances and Meat Quality of Two Italian Pig Breeds Fed Diets for Commercial Hybrids. Meat Science, 71, 713-718. http://dx.doi.org/10.1016/j.meatsci.2005.05.016

[27] Zanardi, E., Novelli, E., Giretti, G.P. and Chizzolini, R. (2000) Oxidative Stability of Lipids and Cholesterol in Salame Milano, Coppa and Parma Ham: Dietary Supplementation with Vitamin E and Oleic Acid. Meat Science, 55, 169-175. http://dx.doi.org/10.1016/S0309-1740(99)00140-0

[28] Moretti, V.M., Madonna, G., Diaferia, C., Mentasti, T., Paleari, M.A., Panseri, G. and Gandini, G. (2004) Chemical and Microbiological Parameters and Sensory Attributes of a Typical Sicilian Salami Ripened in Different Conditions. Meat Science, 66, 845-854. http://dx.doi.org/10.1016/j.meatsci.2003.08.006

[29] Del Nobile, M.A., Conte, A., Incoronato, A.L., Panza, O., Sevi, A. and Marino, R. (2009) New Strategies for Reducing the Pork Back Fat Content in Typical Italian Salami. Meat Science, 81, 263-269. http://dx.doi.org/10.1016/j.meatsci.2008.07.026

[30] Mattson, F.H. and Grundy, S.M. (1985) Comparison of Effects of Dietary Saturated, Monounsaturated and Polyunsaturated Fatty Acids on Plasma Lipids and Lipoproteins in Man. Journal of Lipid Research, 26, 194-202. http://www.jlr.org/content/26/2/194.full.pdf+html?sid=1ea85e17-48df-4a11-a622-10a20ef40cb3

[31] Mayes, A. (1996) Metabolism of Unsaturated Fatty Acids and Eicosanoids. In: Murray, R.K., Granner, D.K., Mayes, P.A. and Rodwell, V.W., Eds., Harper's Biochemistry, Appleton and Lange, Connecticut, 236-244.

[32] Wood, J.D., Richardson, R.I., Nute, G.R., Fisher, A.V., Campo, M.M. and Kasapidou, E. (2003) Effects of Fatty Acids on Meat Quality: A Review. Meat Science, 66, 21-32. http://dx.doi.org/10.1016/S0309-1740(03)00022-6

[33] Maw, S.J., Fowler, V.R., Hamilton, M. and Petchey, A.M. (2003) Physical Characteristics of Pig Fat and Their Relation to Fatty Acid Composition. Meat Science, 63, 185-190. http://dx.doi.org/10.1016/S0309-1740(02)00069-4 
[34] Soto, E., De La Hoz, L., Ordóñez, J.A., Herranz, B., Hierro, E., López-Bote, C.J. and Cambero, M.I. (2009) The Feeding and Rearing Systems of Iberian Pigs Affect the Lipid Composition and Texture Profile of Dry-Cured Loin. Journal of Animal and Feed Sciences, 18, 78-89.

http://www.ifzz.pl/index.php?option=com_sobi2\&sobi2Task=sobi2Details\&sobi2Id=23\&lang=en

[35] Mancini, R.A. and Hunt, M.C. (2005) Current Research in Meat Color. Meat Science, 71, 100-121. http://dx.doi.org/10.1016/j.meatsci.2005.03.003

[36] Petersen, J.S., Henckel, P., Maribo, H., Oksberg, N. and Sorensen, M.T. (1997) Muscle Metabolic Traits, Post MortempH-Decline and Meat Quality in Pigs Subjected to Regular Physical Training and Spontaneous Activity. Meat Science, 46, 259-275. http://dx.doi.org/10.1016/S0309-1740(97)00021-1 